\title{
Canadian Islamic Schools: Unravelling the Politics of Faith, Gender, Knowledge, and Identity
}

\author{
Jasmin Zine \\ Toronto: University of Toronto Press, 2008. 369 pages.
}

Over the last two to three decades, a number of factors have ensured that western Muslims and Islam have become socially and politically far more embedded and visible in western liberal democracies. For example, a large segment of new (post-1965) immigrant religious minority communities settling in western liberal democracies, including Canada, are of the Muslim faith. Moreover, an increasing number of educated, professional westernborn Muslims consider, unlike their immigrant parents, their countries of birth as their "home." Furthermore, the politicization of Islam and the nature of the current state of international affairs, in which issues pertaining to Muslims and Islam often take central place, have highlighted the public prominence of Islam and its adherents in the West.

This situation has problematized and generated a number of debates relating to the philosophical, religious, cultural, political, and social underpinnings of western liberal societies vis-à-vis their Muslim community constituency. In addition, it has induced several profound identity-related questions pertaining to what it means to be "western" or "a western Muslim" or, for some, a "Muslim" in the West. One aspect of this overall dynamic is the question of the role and the function of faith-based Islamic schools operating in western liberal democracies, as their numbers have mushroomed over the last two decades.

The book under review, comprising nine chapters written by Muslim Canadian sociologist Jasmin Zine, is to be seen in this broader macrocosm. The first three chapters explicate its methodological and discursive/philosophical underpinnings. Chapters 4 to 8 discuss and analyze the empirical data in light of the book's overall heuristic. In the final chapter, the author reflects upon the future role that Islamic faith-based schools could play in promoting a healthy and engaged Canadian civil Muslim society and lists several perceptive recommendations and "strategic interventions" to reform and promote academic excellence within them. The book contains both a comprehensive bibliography and a very detailed index.

The author offers us a fascinating insight into the modus operandi and challenges faced by faith-based Islamic schools and their stakeholders in 
Canada. Based on a "critical ethnography" and underpinned by four analytical frameworks (critical faith-based epistemology, anti-colonial, integrative anti-racism, and Foucault-inspired feminist post-structuralism) the book, an expansion of her Ph.D. thesis, cuts across and is of relevance to a number of academic disciplines. As a result, it is of significance to all scholars who are interested not only in religious schooling and education, but also in the areas of immigrants and minorities, race and ethnicity, sociology, and Islamic studies in general.

Critical faith-centred epistemology (CFCE), a foundation of the author's critical inquiry, examines how "faith-centred people can identify, counter, and resist racism, classism, and sexism from a spiritually centred space" (p. 51). This space, however, is at the same time "attentive to the ways in which extremist or fundamentalist religious dogmas can become complicit in these constructions and in the structural and circumstances that sustain them" (ibid.). This is the book's main thrust as it is explored in the context of faithbased Islamic schools.

These multiple analytical lenses guiding Zine's critical inquiry are certainly the book's greatest asset. Her CFCE approach and the philosophical principles upon which it is based do not concur only with the nature of Muslim identity, but are particularly important in understanding the identity dynamics of western(-born) Muslims in the context of being a new immigrant religious minority. The discursive frameworks employed, especially feminist post-structuralism, provide a powerful analytical framework that is able to expose the contested nature of the concept of (Islamic) "tradition" and, in particular, its patriarchal, andocentric nature as lucidly discussed by scholars such as Talal Asad and Asma Barlas.

In combination with the CFCE, the feminist post-structural approach permits Zine to problematize, contest, and challenge the dominant patriarchal and puritanical interpretations of the Islamic tradition (which are also, according to her research, prevalent in the faith-based Islamic schools on which her fieldwork focused) and to open up new hermeneutic spaces that provide alternative, yet still traditionally "authentic," interpretations of the Islamic tradition that are (more) gender egalitarian. From this perspective, Zine's work is in consonance with other recent scholarship written from a critical/progressive Muslim scholars' perspective as embodied in the works of Khaled Abou El Fadl, Amina Wadud, Ebrahim Moosa, Farid Esack, Meena Sharify-Funk, Asma Barlas, Kecia Ali, and others.

Zine's contention that Islamic schools could potentially be sites of production of counter-hegemonic knowledges in the tradition of anti-colonial 
and integrative racism discourses is very exciting; however, as she admits, this possibility is still probably unrealistic. The faith-based schools themselves, as the author rightly asserts, can perpetuate oppression and discrimination based upon patriarchal and puritanical interpretations of religion, as seems to be the case in the Islamic schools she examined. Her research also reveals that the philosophically problematic concept and project of the "Islamization of Knowledge" (not only) in the context of faith-based Muslim schooling falls well short of an organic integration of all knowledge embedded in the overarching "Islamic" cosmovision, its principal objective. In fact, it is employed rather haphazardly and primarily for the purposes of Islamic apologetics and da`wah.

Given its aims, Zine's book would have benefited from incorporating a longer discussion on identity dynamics among western Muslims from the viewpoint of their being a new immigrant religious minority (rather than using the word diaspora, which implies a permanent homeland-oriented mentality that does not correspond with the reality of the majority of western Muslims, in particular those born in the West), especially in relation to the dynamics among religion, culture, and ethnicity. In this context, Zine just quotes a view of a traditionally minded Muslim scholar who considers Islam as being both "a religion and culture" (p. 143). There is considerable scholarly evidence that religion is becoming more detached from the homeland's majority culture/ethnicity and even from any culture for that matter, especially among western-born Muslims and those who espouse puritanical interpretations of the Islamic tradition (as evident in most Islamic schools, as shown by the author). This decoupling of religion and (inherited) culture/ ethnicity results in a new immigration, minority religion-specific, and often "accultural" religious identity.

It is also not clear that two of the four philosophical foundations underpinning CFCE as identified by Zine (peace and social and environmental justice, p. 51) are "inherent in Islam," as she claims. As astutely pointed out by the progressive/critical traditionalist scholars identified above, the predominantly male interpreters of the Islamic tradition find and validate in it that which they already set out to find. Social and environmental justice, in particular, have not often been of much concern to (neo)conservative and traditional Muslim scholarship. This is not to say that these two concepts are not "Islamic" per se, but it shows that what is "Islamic" is primarily determined by (male) interpreters of the Islamic tradition, as Zine repeatedly states. Thus, such assertions as "true Islamic faith" (p. 193) are not really helpful. In this context, and given the emphasis on the criticality in her book, I would also 
mention that instead of using such phrases as Islamic schools or Islamic dress (e.g., p. 153), the author could have used different terminology, such as faithbased Muslim schools and Qur'anically required modest dress to highlight the notion of agency of the interpreters of its normative sources.

Similarly, employing such words as Islamophobia and gendered Islamophobia are not entirely accurate either. Generally speaking, over the last century or so Islam, as a religious phenomenon and object of academic study, has been studied far more "objectively," even sympathetically. It is the women and men of Islamic faith (in particular those who wear easily visible traditional religious symbols) who are feared, mistrusted, and considered dangerous or possibly as having an Islamic "fundamentalist" mentality. Thus, employing alternative terminology such as Muslimophobia or (gendered) Muslimahphobia would be more accurate.

Additionally, throughout her book Zine employs the word gender equity. One wonders why the word gender equality/justice/egalitarianism was not employed instead, especially since equity is frequently used in contemporary neo-conservative Muslim discourses to argue that women, based on their "different divinely ordained nature," along the "biology is women's destiny" lines of arguing (both of which are antithetical to Zine's own view), cannot be "equal" to men and thereby effectively undermine many of women's social, political, and legal rights. I hope that these omissions are much more than just a play of semantics, especially given Zine's rightful special attention and commitment to critical/progressive (Muslim) thought.

The above notwithstanding, Zine's book is a major contribution to understanding the dynamics of faith-based Islamic schools and their various stakeholders operating in western liberal democracies. Moreover, it is a first of its kind and an important contribution to broader Islamic thought, as it is a valuable addition to the existing body of literature written by the progressive/ critical traditional scholars (referred to above) who wish to bring change, especially in the areas of social and gender justice, to Muslim thought, which is still socially hegemonic pre-modern and neo-conservative. Significantly, it is a potent reminder that these discourses will not be easily "adopted" by the larger Muslim community, although the author's research suggests that some aspects of feminist thought (e.g., agency, academic excellence, and public engagement) are being espoused by some of the Muslim teachers and students she interviewed. 